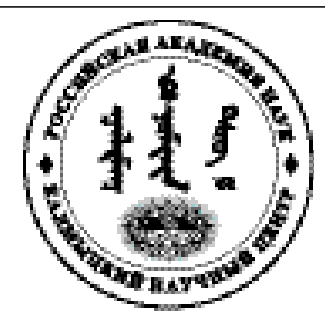

Published in the Russian Federation

Oriental Studies (Previous Name: Bulletin of the Kalmyk Institute

for Humanities of the Russian Academy of Sciences)

Has been issued as a journal since 2008

ISSN: 2619-0990; E-ISSN: 2619-1008

Vol. 13, Is. 5, pp. 1271-1291, 2020

DOI: $10.22162 / 2619-0990-2020-51-5-1271-1291$

Journal homepage: https://kigiran.elpub.ru

УДК 903.2 (470.57)

DOI: $10.22162 / 2619-0990-2020-51-5-1271-1291$

\title{
Стоянка среднего палеолита в пещере Иманай-1 на Южном Урале: предварительные итоги археологических исследований
}

\author{
Вячеслав Георгиевич Котов ${ }^{1}$, Михаил Михайлович Румянцев ${ }^{2}$, \\ Дмитрий Олегович Гимранов ${ }^{3}$
}

${ }^{1}$ Институт истории, языка и литературы Уфимского федерального исследовательского центра РАН (71, пр. Октября, 450054 Уфа, Российская Федерация) кандидат исторических наук, старший научный сотрудник iD 0000-0002-3510-0058. E-mail: kslav1@yandex.ru

${ }^{2}$ Институт истории, языка и литературы Уфимского федерального исследовательского центра РАН (71, пр. Октября, 450054 Уфа, Российская Федерация)

научный сотрудник

iD 0000-0003-2787-3074. E-mail: rmm121983@mail.ru

${ }^{3}$ Институт экологии растений и животных Уральского отделения РАН (д. 202, ул. 8 марта, 620144 Екатеринбург, Российская Федерация)

кандидат биологических наук, старший научный сотрудник

iD 0000-0002-9592-5211. E-mail: djulfa250@rambler.ru

(C) КалмНЦ РАН, 2020

(C) Котов В. Г., Румянцев М. М., Гимранов Д. О., 2020

Аннотация. Введение. Пещера Иманай-1 - новый памятник среднего палеолита на Южном Урале, открытый авторами в 2009 г. Он расположен на западном сколе Уральской горной системы, в междуречье рек Белая и Нугуш, на границе горно-лесной и степной зон. Цель статьи - введение в научный оборот предварительных результатов археологических исследований памятника Иманай-1. Результатыл. Пещера туннельного типа, ход длиной 70 м заканчивается дальним залом. В этом зале были собраны кости малого пещерного медведя и пещерного льва. Памятник является многослойным. В 1 культурном горизонте было обнаружено 399 изделий из камня и кости. Орудия составляют 60 \% от всех изделий из камня, нуклеусы и чешуйки отсутствуют, следовательно, первичная и вторичная обработка осуществлялись за пределами Дальнего зала. Каменная индустрия характеризуется использованием осколков и аморфных сколов из кремня. Рабочие участки оформлялись монофациальной и бифациальной ретушью, резцовым сколом. Орудия представлены следующими типами: 3 мустьерских бифациальных остроконечника, 4 конвергентных скребла с бифациальной обработкой, обушковые ножи, некоторые с бифациальной обработкой - 6 экз., резчики на осколках и аморфных 
сколах - 229 экз. (59 \%), острия - 19 экз. (5 \%), орудия с шипом - 13 экз. (3\%), резцы 21 экз. (5 \%). В основании 1 культурного горизонта был найден череп малого пещерного медведя с искусственным отверстием, оставленным каменным наконечником копья. Индустрия памятника находит многочисленные аналогии на стоянке Ильская-1 на Северном Кавказе и в материалах верхнего слоя грота Киик-Коба в Крыму, а также на других памятниках среднего палеолита тейякской традиции. Три некалиброванные даты показывают интервал от 26 до 42 тыс. лет. Это указывает на финал мустьерской эпохи.

Ключевые слова: пещерная стоянка, средний палеолит, тейяк, типология, технология, Южный Урал

Благодарность. Исследование выполнено за счет гранта Российского научного фонда (проект № 20-74-00041).

Для цитирования: Котов В. Г., Румянцев М. М., Гимранов Д. О. Стоянка среднего палеолита в пещере Иманай-1 на Южном Урале: предварительные итоги археологических исследований // Oriental Studies. 2020. T. 13. № 5. C. 1271-1291. DOI: 10.22162/2619-0990-2020-51-5-12711291

UDC $903.2(470.57)$

DOI: $10.22162 / 2619-0990-2020-51-5-1271-1291$

\title{
Middle Paleolithic Site of Imanai-1 Cave in the Southern Urals: Preliminary Results of Archaeological Investigations
}

\author{
Vyacheslav G. Kotov ${ }^{1}$, Mikhail M. Rumyantsev², Dmitry O. Gimranov ${ }^{3}$
}

${ }^{1}$ Institute of History, Language and Literature of the Ufa Federal Research Centre of the RAS (71, Oktyabrya Ave., Ufa 450054, Russian Federation)

Cand. Sc. (History), Senior Research Associate

iD 0000-0002-3510-0058. E-mail: kslav1@yandex.ru

${ }^{2}$ Institute of History, Language and Literature of the Ufa Federal Research Centre of the RAS (71, Oktyabrya Ave., Ufa 450054, Russian Federation)

Research Associate

iD 0000-0003-2787-3074.E-mail: rmm121983@mail.ru

${ }^{3}$ Institute of Plant and Animal Ecology of the Ural Branch of the RAS (202, 8 Marta St., Yekaterinburg 620144, Russian Federation)

Cand. Sc. (Biology), Senior Research Associate

(iD)0000-0002-9592-5211. E-mail: djulfa250@rambler.ru

(C) KalmSC RAS, 2020

(C) Kotov V. G., Rumyantsev M. M., Gimranov D. O., 2020

\begin{abstract}
Introduction. Imanai-1 Cave is a new monument of the Middle Paleolithic in the Southern Urals. It was discovered by the authors in 2009 and is located in the west of the Ural mountain system, in the interfluve of the Belaya and Nugush Rivers, on the border of the mountain-forest and steppe zones. Goals. The paper aims to introduce preliminary results of archaeological investigations into scientific discourse. Results. The cave is of a tunnel type, its $70 \mathrm{~m}$ long passage ending with a far hall which contained bones of a small cave bear and a cave lion. The monument is multi-layered. The first cultural horizon contained 399 items of stone and bone. Tools make up to $60 \%$ of all stone products, while cores and scales are absent, therefore, primary and secondary processing was carried out outside the far hall. The stone industry is characterized by the use of shards and amorphous flint chips. The working areas were made out with monofacial and bifacial retouching, incisal cleavage.
\end{abstract}


The tools are of the following types: 3 Mousterian bifacial points, 4 convergent side-scrapers with bifacial processing, butt knives, some with bifacial processing - 6 items, carvers on fragments and amorphous chips - 229 items (59\%), points - 19 items (5\%), tools with a thorn -13 items (3\%), incisors -21 items $(5 \%)$. At the base of the first cultural horizon, a skull of a small cave bear with an artificial hole made with a stone spearhead was found. The industry of the site has numerous analogies at the Ilskaya-1 site in the North Caucasus and in the materials of the upper layer of the Kiik-Koba grotto in the Crimea, as well as at other sites of the Middle Paleolithic of the Tayacian tradition. Three uncalibrated dates show the interval from 26 to 42 thousand years. This indicates the finale of the Mousterian era.

Keywords: cave site, Middle Paleolithic, Tayacian, typology, technology, Southern Urals

Acknowledgments. The reported study was granted by Russian Science Foundation, project no. 20 74-00041.

For citation: Kotov V. G., Rumyantsev M. M., Gimranov D. O. Middle Paleolithic Site of Imanai-1 Cave in the Southern Urals: Preliminary Results of Archaeological Investigations. Oriental Studies. 2020. Vol. 13(5): 1271-1291. (In Russ.). DOI: 10.22162/2619-0990-2020-51-5-1271-1291

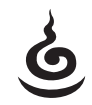

\section{Введение}

До недавнего времени на Южном Урале было известно только два стратифицированных памятника среднего палеолита с фауной - это стоянка Богдановка на р. Урал в Челябинской области [Широков и др. 2011] и стоянка Новобелокатайская на северо-востоке Башкортостана [Котов 2008]. Коллекции каменных орудий, обнаруженных на этих памятниках, немногочисленны, что не дает надежных оснований для определения их культурной принадлежности. В этой связи большое значение имеет открытие нового стратифицированного памятника с богатой фауной и многочисленным собранием каменных орудий в пещере Иманай-1 (Барсучья Нора) на западном склоне Южного Урала.

Пещера расположена в Мелеузовском районе Республики Башкортостан, в 5 км к востоку от пос. Нугуш, в урочище Иманай, $53^{\circ} 02^{\prime}$ с.ш., 56 $31^{\prime}$ в.д. (рис. 1: $A$ ). Она находится в левом борту дола Иманай, на высоте 30 м от уровня урочища Иманай, высота над уровнем моря составляет 266 м (рис. 1: Б). Борта долины густо поросли широколиственным лесом и кустарником. Со стороны долины пещера не видна. Вход находится в воронке и закрыт от взора насыпью высотой 2 м. Он имеет вид узкой щели около 1,5 м шириной и 0,5 м высотой, ориентирован на юг-юго-восток (рис. 2: A).

Пещера разработана в толще девонских известняков и представляет собой коридор, тянущийся с юга на север. Входной туннель в виде узкого хода длиной 10 м. Пол его сложен из гумуса. Далее пещера в виде коридора 2 м шириной и 3 м высотой тянется уступами, покрытыми крупными камнями, под углом $11^{\circ}$ вверх на расстояние 70 м. Туннель заканчивается небольшим залом размером $2 \times 4 \times 3$ м, пол которого на 2 м ниже ложа самого туннеля (рис. 3; 4). Пол в этом зале сложен из светло-бурого суглинка с крупной и средней растворенной щебенкой известняка. В заполнении встречаются мелкие кремневые галечки и куски кремня средней величины. На поверхности много крупных и средних камней известняка, а также крупных глыб (рис. 2: Б).

Исследования в пещере проводились в 2009, 2015-2016 гг. совместно двумя отрядами: археологический - от Института истории, языка и литературы Уфимского федерального исследовательского центра РАН (ИИЯЛ УФИЦ РАН; рук. В. Г. Котов) и палеонтологический - от Института экологии растений и животных Уральского отделения РАН (ИЭРиЖ УрО РАН; рук. Д. О. Гимранов) [Котов 2009; Котов 2015].

\section{Палеонтологические исследования}

При визуальном обследовании пещеры на поверхности были обнаружены многочисленные кости, большая часть из которых находилась в дальнем зале (рис. 4). Здесь были зафиксированы скопления костей плейстоценовой сохранности: все они желтовато-красного цвета, рыхлые, на из- 

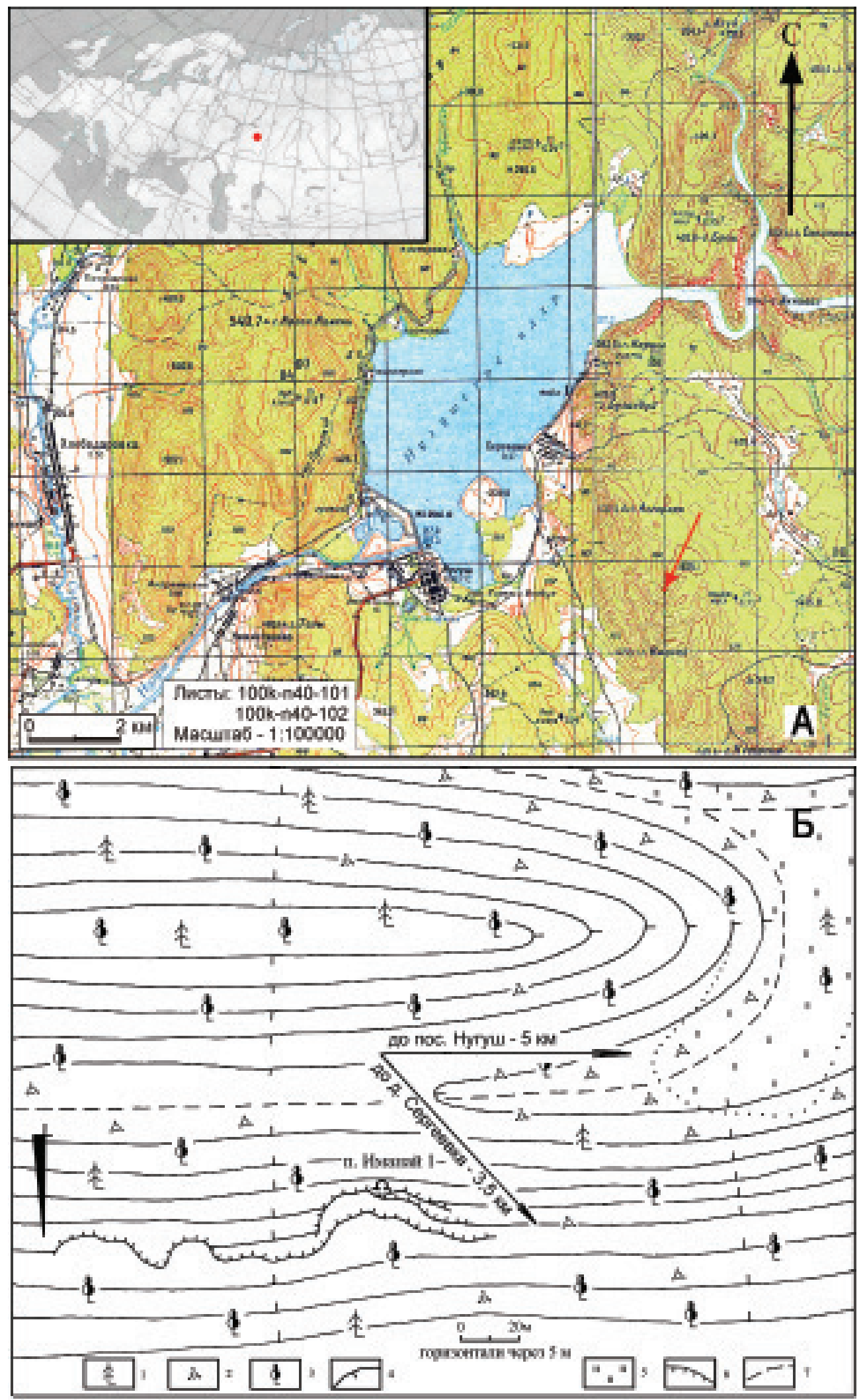

Puc. 1. Местонахождение пещеры Иманай-1. А - Карта местности с местонахождением пещеры Иманай-1 (Барсучья Нора) (указана красной точкой и стрелкой). Б - Пещера Иманай-1, ситуационный план. Условные обозначения: 1 деревья; 2 - кустарник; 3 - скала; 4 - горизонтали; 5 - луг; 6 - обрыв или границы ямы; 7 - тропинка.

[Fig. 1. Location of Imanai-1 Cave. A - Map of the area (Badger Sett) (indicated by the red dot and arrow). B - Imanai-1 Cave, situational plan. Legend: 1 - trees; 2 - bush; 3 - rock; 4 - horizontals; 5 - meadow; 6 - cliff or pit boundaries; 7 - path] 

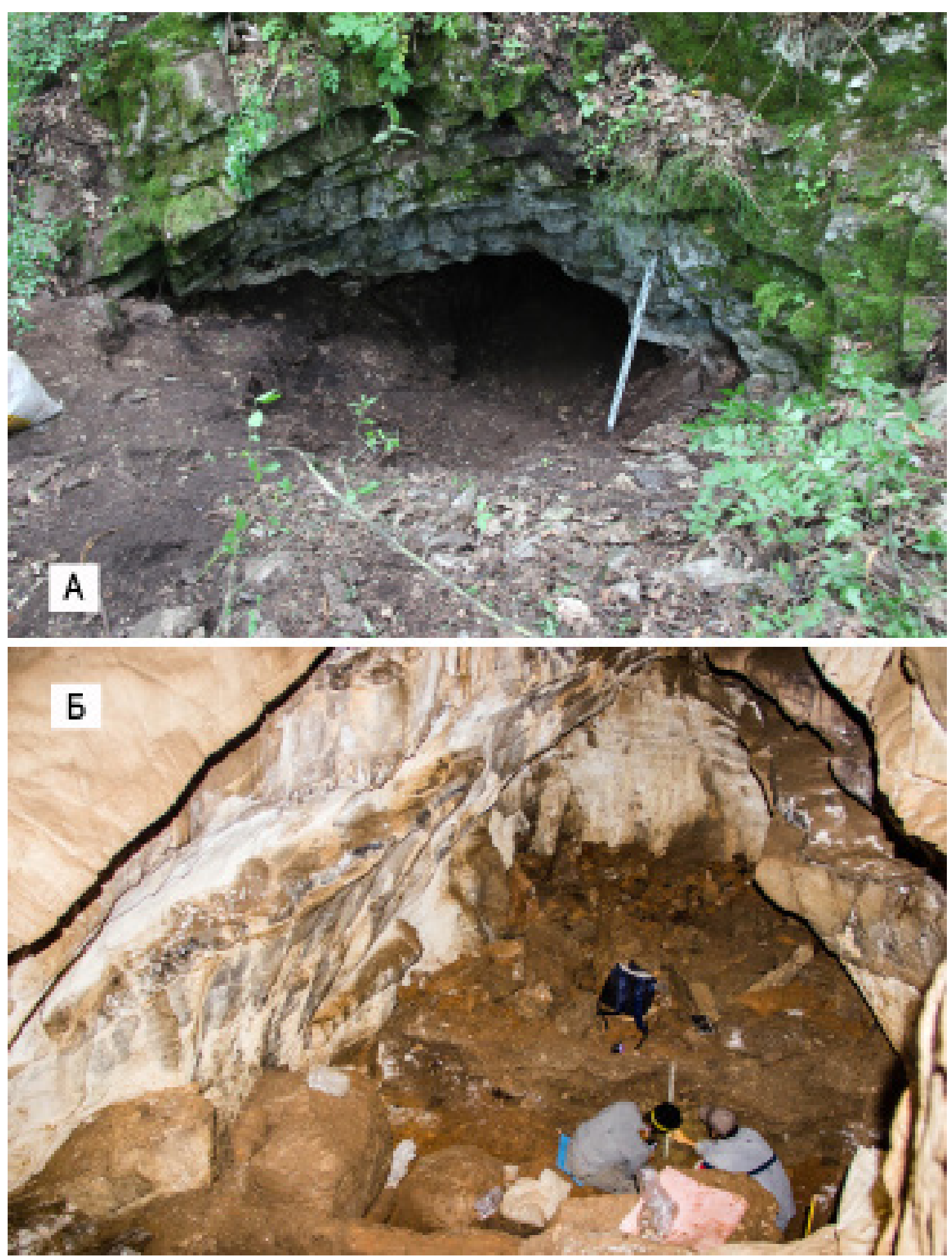

Puc. 2. Пещера Иманай-1. А — вход в пещеру, вид с юга. Б - вид на Дальний зал с севера. Фото В. Г. Котова

[Fig. 2. Imanai-1 Cave. A - entrance to the cave, view from the south. B - view of the Far Hall from the north. Photo by V. Kotov] 


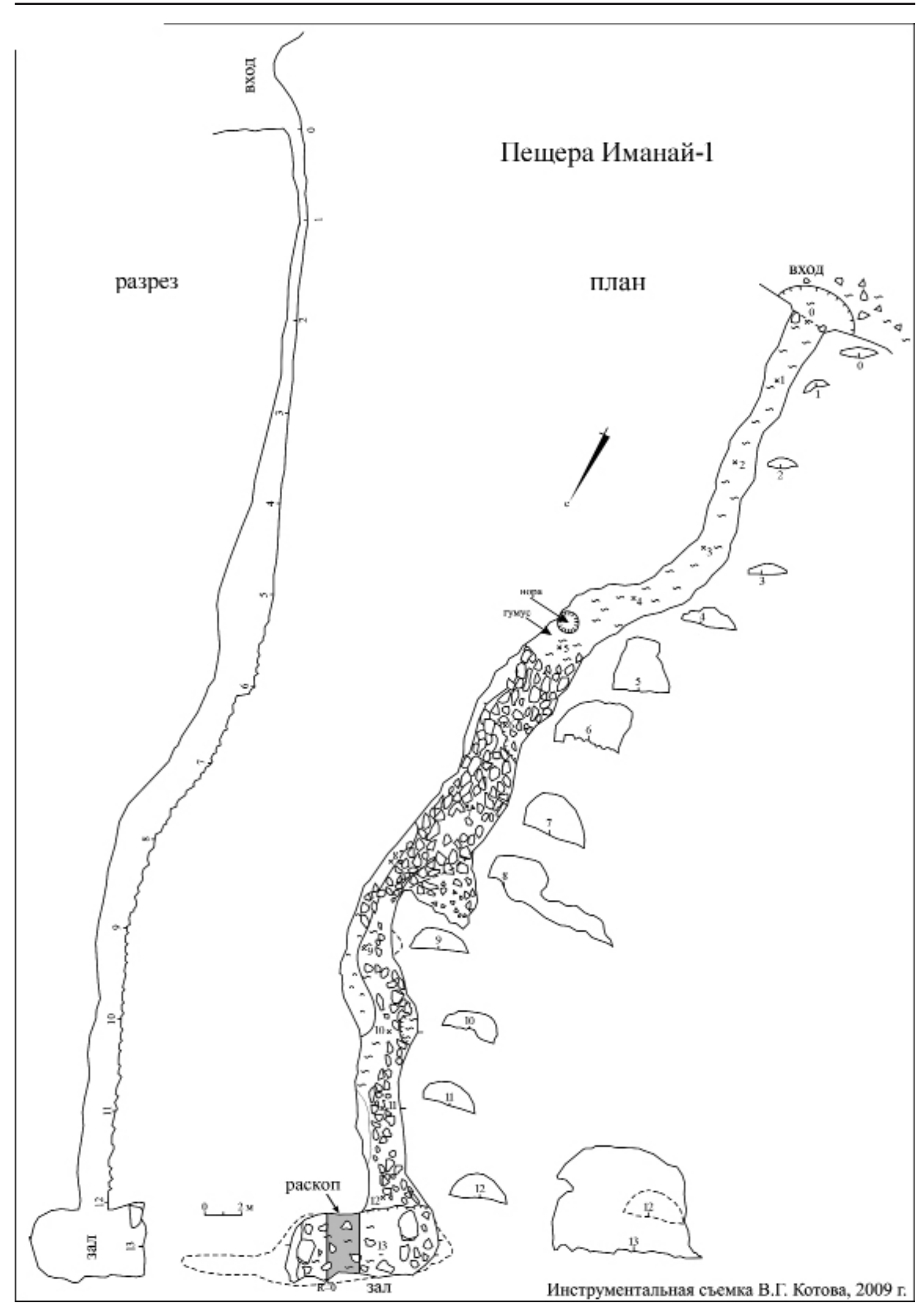

Рuc. 3. Пещера Иманай-1. Разрез, план и сечения

[Fig. 3. Imanai-1 Cave. Profile, plan and sections] 


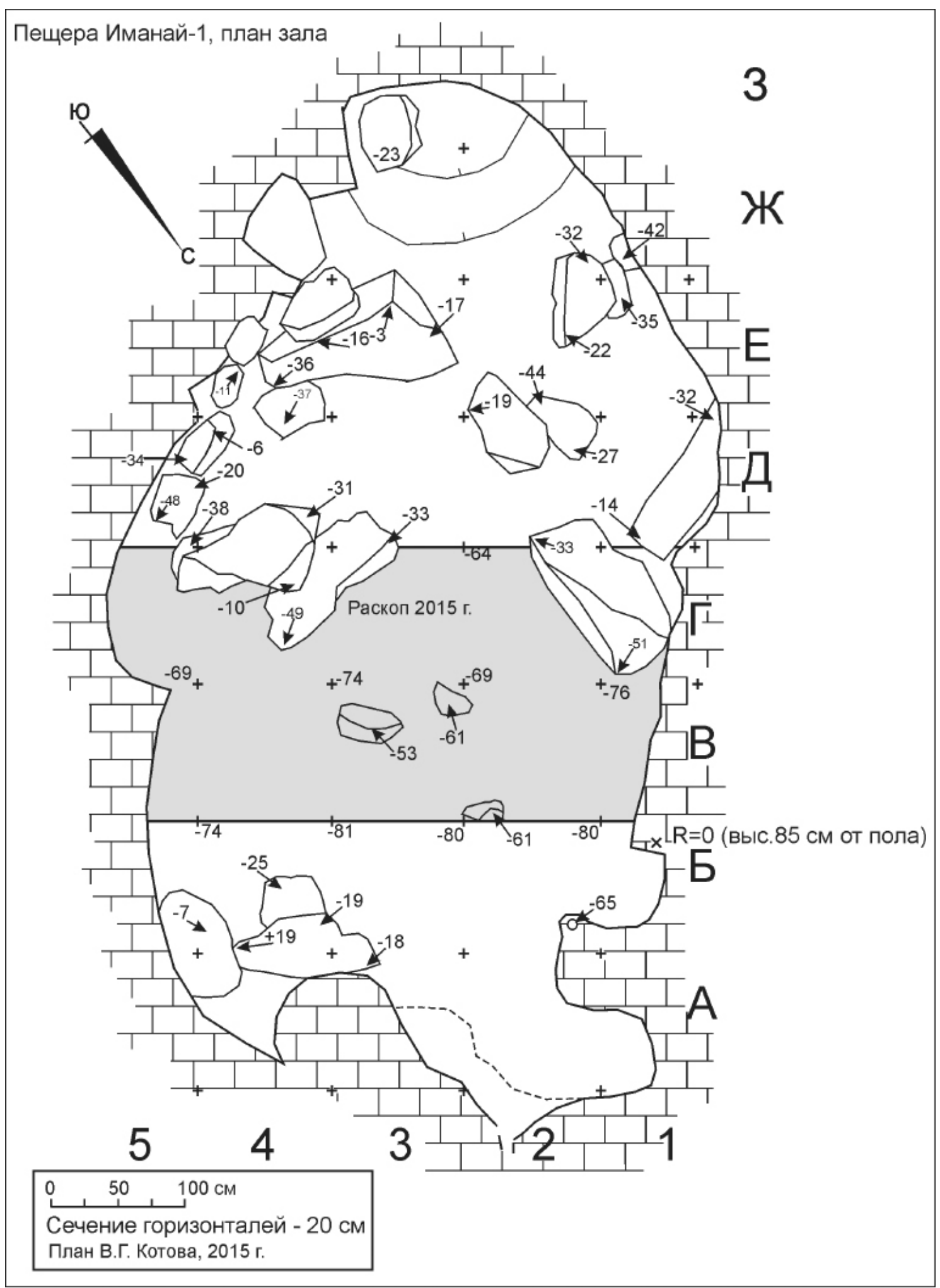

Puc. 4. Пещера Иманай- 1. План Дальнего зала с раскопом 1

[Fig. 4. Imanai-1 Cave. Plan of the Far Hall with excavation site 1] 


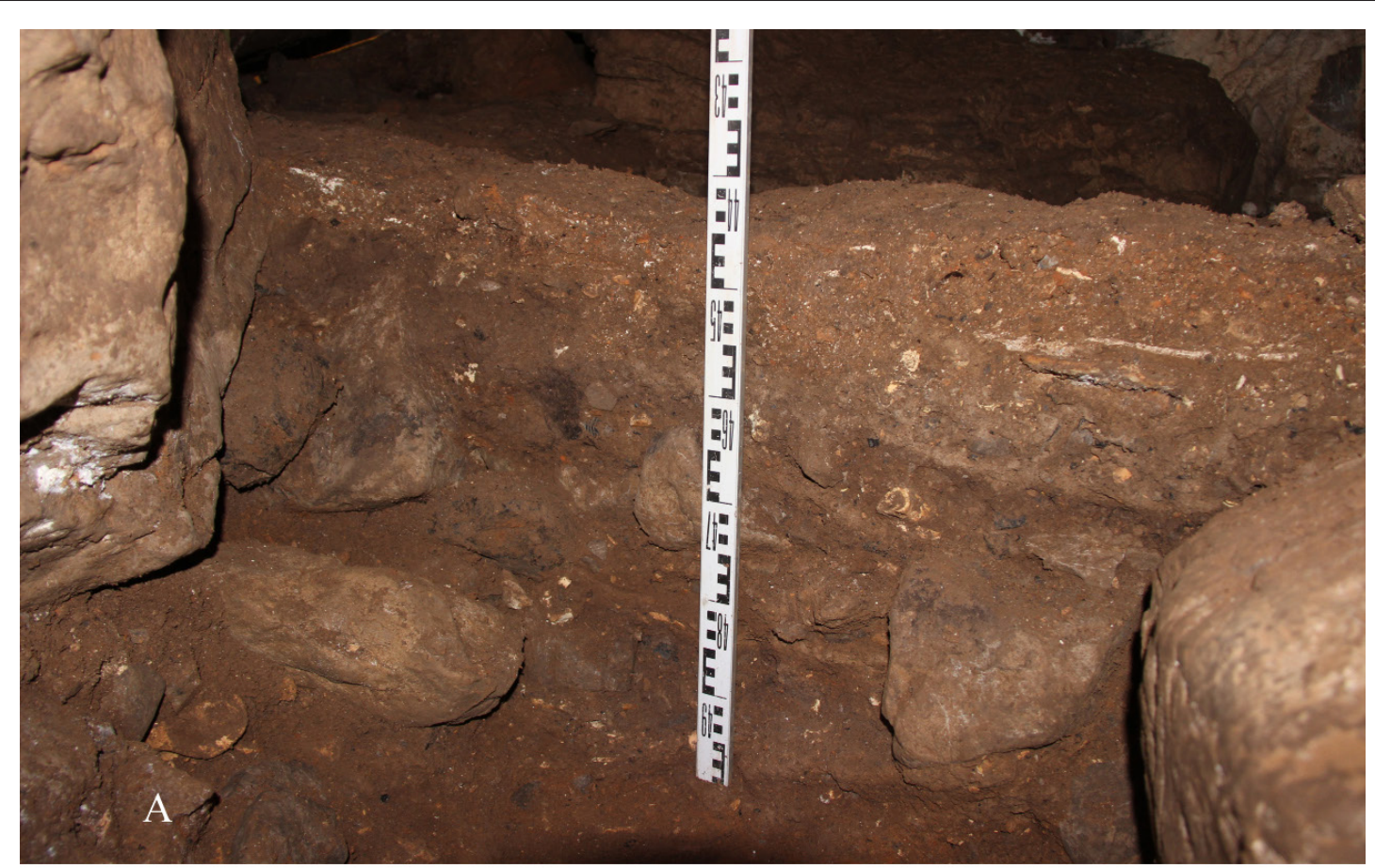

\section{Б}

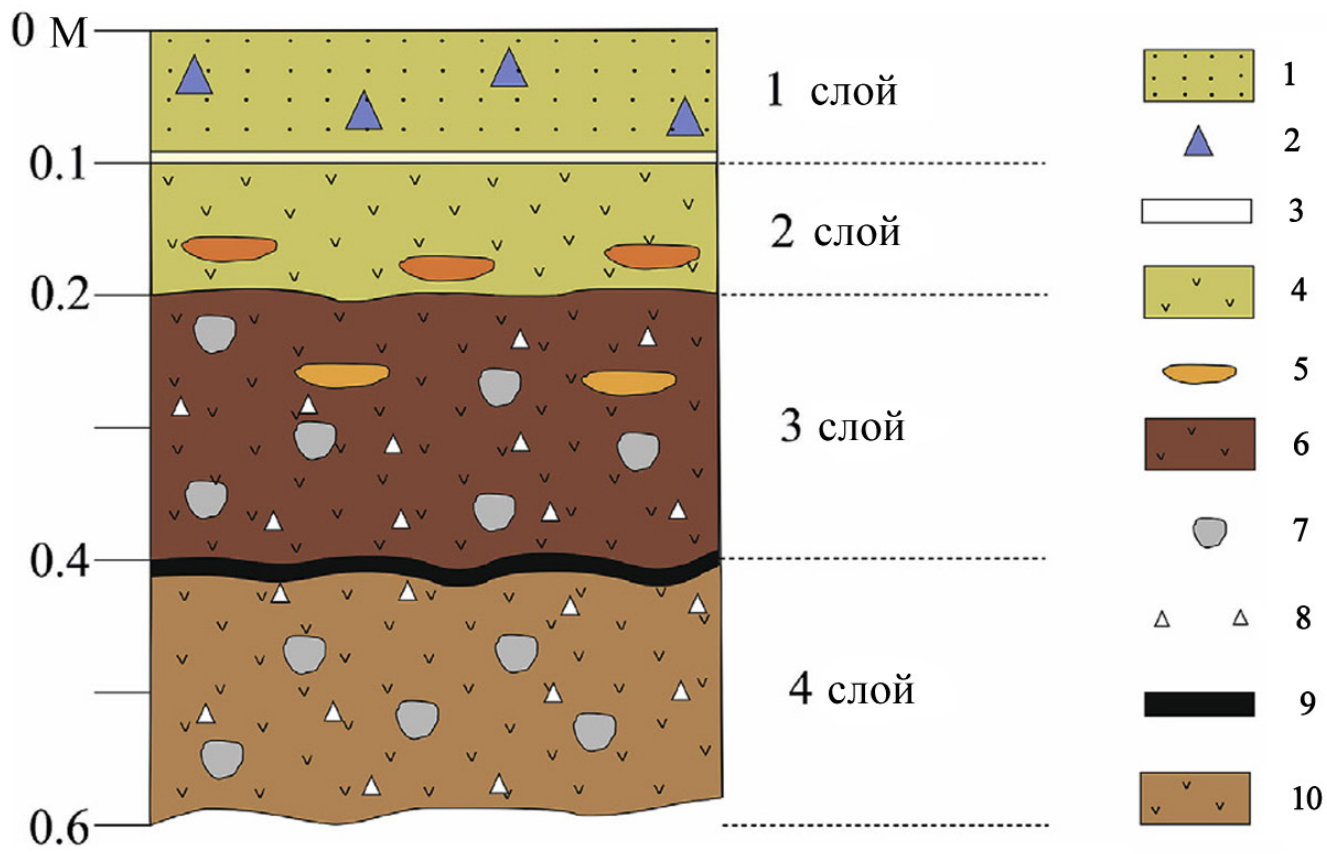

Puc. 5. Пещера Иманай-1. Разрез культурных отложений. А 一 фото южной стенки, Б - разрез отложений (по: [Gimranov, Kosintsev 2020]). Условные обозначения: 1 - супесь светло-коричневая с гравием; 2 - палеолитические каменные изделия; 3 - разломанная кальцитовая корка; 4 - супесь светло-коричневая с доломито-известняковой щебенкой; 5 - известняковый туф; 6 - супесь темно-коричневая с доломито-кальцитовым гравием; 7 - галька угловатая; 8 - известняковая щебенка; 9 - известняко-

вая супесь, насыщенная гравием; 10 - супесь коричневая с доломито-кальцитовым гравием

[Fig. 5. Imanai-1 Cave. Section of cultural deposits. A - photo of the southern wall, B - sediment section [after: Gimranov, Kosintsev 2020]. Legend: 1 - light brown sandy loam with gravel; 2 — Paleolithic stone products; 3 - fractured calcite crust; 4 — light brown sandy loam with dolomite-limestone gravel; 5 - limestone tuff; 6 - dark brown sandy loam with dolomite-calcite gravel; 7 - angular pebble; 8 - crushed limestone; 9 - limestone sandy loam saturated with gravel; 10 — brown sandy loam with dolomite-calcite gravel] 
лом крошатся. Всего же за три года исследований общее количество идентифицируемых костей плейстоценовой сохранности превышает 10000 образцов. Количество костей голоценовой сохранности - более 1 000. Основная масса костных остатков плейстоценовой сохранности принадлежит малому пещерному медведю (Ursus ex gr. savini-rossicus) и составляет $93 \%$. Намного реже встречаются кости сурка (Marmota sp.), зайца (Lepus sp.), бобра (Castor fiber), пещерного льва (Panthera ex gr. fossilisspelaea), красного (Cuon sp.) и серого (Canis lupus) волков, песца ( $V$. lagopus) и лисицы (V. vulpes), барсука (Meles sp.), росомахи (Gulo gulo), горностая (Mustela erminea), хоря (M. ex gr. putorius-eversmanii), бурого медведя (U. arctos), гималайского медведя (U. thibetanus), мамонта (Mammuthus primigenius) лошади (Equus ferus), носорога (Rhinocerotidae gen. indet), первобытного бизона (Bison priscus), сайги (Saiga tatarica) и барана (Ovis ammon) [Gimranov, Kosintsev 2020].

Биохимический и минералогический анализы показали, что кости пещерного льва (Panthera ex gr. fossilis-spelaea) существенно древнее других костей и, в частности, костных остатков малого пещерного медведя (Ursus ex gr. savini-rossicus) [Gimranov et al. 2018: 193]. Массовое захоронение львов образовалось в результате естественной гибели животных, которое сформировалось в первой половине - середине позднего неоплейстоцена (OIS5-3) [Гимранов и др. 2018: 233]. В целом накопление костных остатков происходило в результате как естественной гибели животных и жизнедеятельности хищных млекопитающих (следов искусственного воздействия, а также огня на них не обнаружено), так и человека [Гимранов и др. 2016: 233]. Абсолютное большинство костей животных (99\%) происходит из верхних горизонтов до глубины 0,6 м [Gimranov, Kosintsev 2020].

\section{Археологические исследования}

В дальнем зале по его поперечной оси

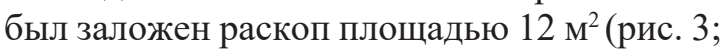
4). Отложения разбирались зачистками с фиксацией находок на уровне условных горизонтов по 10 см. В результате исследований 2015 г. отложения были вскрыты до глубины 0,6 м и было выявлено четыре геологических слоя (рис. 5):

1. Супесь светло-коричневая с известняковой щебенкой и кусками черного кремня. Внутри слоя была обнаружена линза бурого суглинка с известняковой крошкой и отдельными кусками кремня. На поверхности линзы были зафиксированы кусочки красной и оранжевой охры, а также отдельные угольки. В заполнении встречены многочисленные кости животных и каменные изделия эпохи палеолита. Данный слой полностью соотносится с первым культурным слоем. В основании слоя присутствует фрагментированная кальцитовая корка толщиной 3-4 мм. Контакт с нижележащим слоем четкий. Мощность - 0,1 м.

2. Супесь светло-коричневая с доломитово-известняковой растворенной щебенкой. Внутри слоя в большом количестве обнаружены кости животных и каменные изделия эпохи палеолита. В основании слоя зафиксирована прослойка серовато-коричневого суглинка толщиной 2-3 см. Контакт с нижележащим слоем четкий. Мощность $0,1-0,15 \mathrm{M}$.

3. Супесь темно-коричневая с доломито-кальцитовым гравием и кусками кремня. В заполнении слоя присутствуют многочисленные кости животных. В основании слоя залегает прослойка известняковой супеси, насыщенная гравием. Контакт с нижележащим слоем четкий. Мощность - 0,2 м.

4. Супесь коричневая с доломито-кальцитовым гравием и кусками кремня. Встречаются кости животных. Выявленная мощность - 0,2 м.

Были получены три некалиброванные даты: две по костям пещерного медведя и одна по кости пещерного льва: 26320 \pm 1790 (GIN-14244), $34940 \pm 140$ (IGAN$5652), 42410 \pm 260$ (IGAN-5652) [Gimranov, Kosintsev 2020].

В стенах пещеры присутствуют включения желваков черного и серого кремня. Куски черного и серого трещиноватого кремня встречаются как на полу, так и внутри отложений. Кремень из пещеры темно-серых оттенков отличается трещиноватостью и при раскалывании рассыпается на бесформенные осколки. Большая часть орудий сделана из качественного кремня светло-серых оттенков, который был принесен в пещеру. 


\section{Археологический материал}

Всего в раскопе на уровне 1-го слоя обнаружено 399 изделий из камня и кости (табл. 1). Здесь была получена достаточно представительная коллекция каменных орудий. Вместе с изделиями из камня были найдены угольки, кусочки охры и кости плейстоценовых животных. Обращает на себя внимание то, что орудия составляют $80 \%$ от всех каменных изделий, полноценные нуклеусы отсутствуют, а нуклевидные формы представлены аморфными кусками кремня -8 экз. (2\%), расколотые вдоль или же имеющие отдельные негативы сколов, причем снятых с неподготовленных ударных площадок. Сколы аморфные с бессистемной огранкой -60 экз. (15\%). Пластины единичные - 3 экз. (1 \%). В промывке не были обнаружены чешуйки и мелкие сколы. Все это указывает на то, что раскалывание нуклеусов с целью получения заготовок и обработка орудий осуществлялись за пределами этого зала, и, скорее всего, вне пещеры.

Подавляющее большинство орудий было изготовлено из аморфных сколов и осколков. В целом коллекция каменных орудий производит впечатление своим архаизмом в первичной и вторичной обработке.

В 1 культурном слое были зафиксированы 3 мустьерских бифациальных остроконечника и 4 конвергентных скребла с бифациальной обработкой (рис. 6).

Самый крупный мустьерский бифациальный остроконечник вытянутой иволистной формы имеет размер $9 \times 3,5 \times 2$ см (рис. 6 : 5). Он имеет плоско-выпуклую форму. На выпуклой стороне левая пологая грань была создана краевыми широкими продольными сколами. Правая грань на большей части сохраняет естественную поверхность, на дистальном участке она сформирована краевыми пологими сколами. Край лезвия выровнен мелкой ретушью. Правый фас образован радиальными пологими широкими сколами, грани уплощены пологими среднего размера удлиненными фасетками ретуши, края дополнительно были выровнены мелкой ретушью. Кончик острия обломан и затем был приострен мелкой ретушью.

Другой остроконечник напоминает маленькое рубило, он имеет укороченную форму и закругленное основание, обе вы- пуклые поверхности образованы радиальными сколами, дистальная часть обломана, размер: $4,9 \times 3,9 \times 1,8 \mathrm{~cm}$ (рис. 6: 6).

Третий остроконечник изготовлен на массивном укороченном отщепе подтреугольной ассиметричной формы с выпуклыми боковыми лезвиями и скошенным прямым основанием, левый фас сформирован радиальными сколами, края с обеих сторон обработаны крупной полукрутой ретушью разного размера, размер: $5,7 \times 3,8 \times 1,2 \mathrm{~cm}$ (рис. 6: 7).

Два конвергентных скребла имеют миндалевидную форму. Они в профиль обладают плоско-выпуклой формой. Брюшко создано плоскими радиальными сколами, спинка выпуклая, образована радиальными удлиненными снятиями, кромка выравнивалась более мелкой ретушью. Основание закругленное в плане и массивное в профиль. Размер одного орудия: $4,5 \times 2,8 \times 1,5 \mathrm{~cm}$ (рис. 6: 1). Размер другого изделия: $5,3 \times 3 \times 1,8$ см (рис. 6: 3).

Два других скребла обладают естественными основаниями, сохраняющими участки выпуклой поверхности галечной корки. Боковые грани образованы полукрутой и пологой разнокалиберной крупной ретушью. Лезвия были дополнительно выровнены мелкой ретушью. Слегка закругленные вершины на обоих изделиях были с двух сторон подправлены сколами удлиненной пологой ретуши продольной и радиальной направленности. Размеры изделий следующие: $4,4 \times 3,5 \times 1,5$ см и $5 \times 3,3 \times 1,3 \mathrm{~cm}$ (рис. 6: 2, 4).

Достаточно крупной серией - 11 экз. (2 \%) представлены простые скребла. Часть из них имеют бифациальную обработку поверхностей и рабочих участков (рис. $7: 8,9$, 10, 11). Также в коллекции присутствуют орудия верхнепалеолитического облика, в частности, скребки -8 экз. (2\%) (рис. 7 : $1-7,12)$. Большая часть их имеет небольшие размеры, рабочие участки и боковые края оформлены вертикальной ретушью (рис. 7: 1, 2, 4, 6, 7, 13). У нескольких скребков ретушью или выемками был выделен рабочий участок, это, так называемые «скребки с рыльцем» (рис. 7: 3, 5, 12). Одно орудие комбинированное изготовлено на укороченном отщепе, у него полукрутой и пологой ступенчатой ретушью обработаны таким образом края, что они образовали слегка 
Таблий 1. Находки в пещере Иманай-1, раскоп 1

[Table 1. Finds from Imanai-1 Cave, excavation site 1]

\begin{tabular}{|c|c|c|c|}
\hline № & Тип изделия & Общее кол-во & $\%$ \\
\hline 1 & Нуклевидные формы & 8 & 2 \\
\hline 2 & Отщепы/сколы & 60 & 15 \\
\hline 3 & Осколки & 5 & 1 \\
\hline 4 & Отщеп с ретушью & 6 & 1,2 \\
\hline 5 & Пластина/пластинчатый отщеп & 3 & 1 \\
\hline 6 & Пластина с ретушью & 2 & 0,5 \\
\hline 7 & Резчик & 229 & 57 \\
\hline 8 & Острие & 19 & 5 \\
\hline 9 & Резец & 21 & 5 \\
\hline 10 & Острие-проколка & 1 & 0,2 \\
\hline 11 & Резчик-резец & 3 & 1 \\
\hline 12 & Скребло-резец & & \\
\hline 13 & Резчик-скребло & 6 & 1,5 \\
\hline 14 & Резчик-скребок & 3 & 1 \\
\hline 15 & Орудие с шипом & 3 & 1 \\
\hline 16 & Резец-резчик-скребок & 2 & 0,5 \\
\hline 17 & Отбойник & 1 & 0,2 \\
\hline 18 & Острие-резчик & 1 & 0,2 \\
\hline 19 & Остроконечник бифациальный & 1 & 0,2 \\
\hline 20 & Нож обушковый & 2 & 0,5 \\
\hline 21 & Скребло конвергентное & 3 & 0,7 \\
\hline 22 & Скребло двойное & 1 & 0,2 \\
\hline 23 & Скребло продольное & 2 & 0,5 \\
\hline 24 & Скребло поперечное & 3 & 0,7 \\
\hline 25 & Скребло зубчатое & 1 & 0,2 \\
\hline 26 & Скребло угловатое & 1 & 0,2 \\
\hline 27 & Скребок & 8 & 2 \\
\hline 28 & Резец-скребок & 1 & 0,2 \\
\hline & Всего & 396 & 100 \\
\hline
\end{tabular}



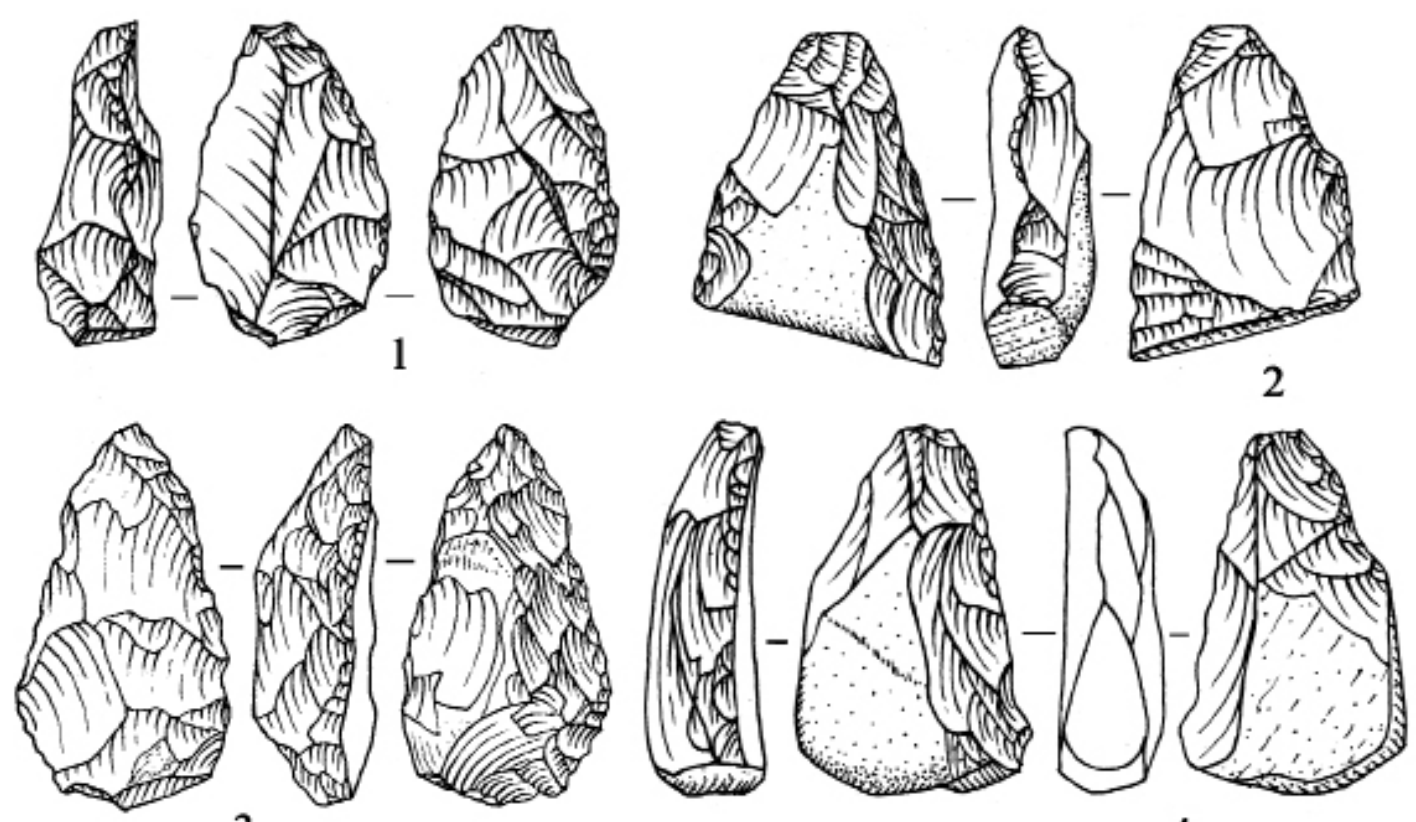

3
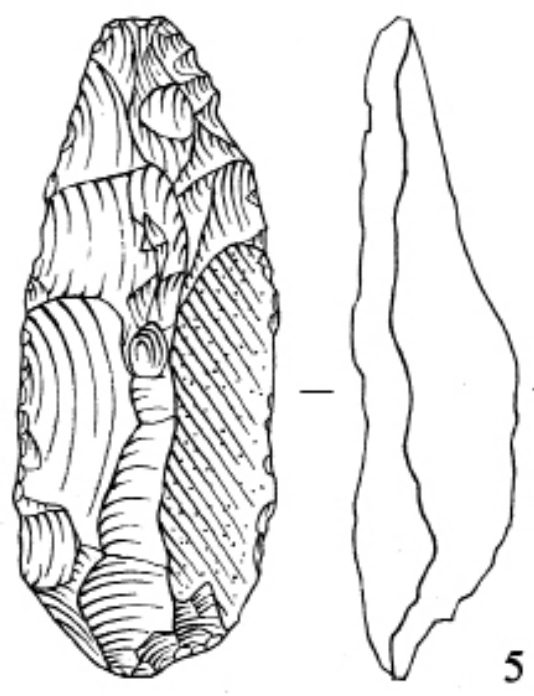

4
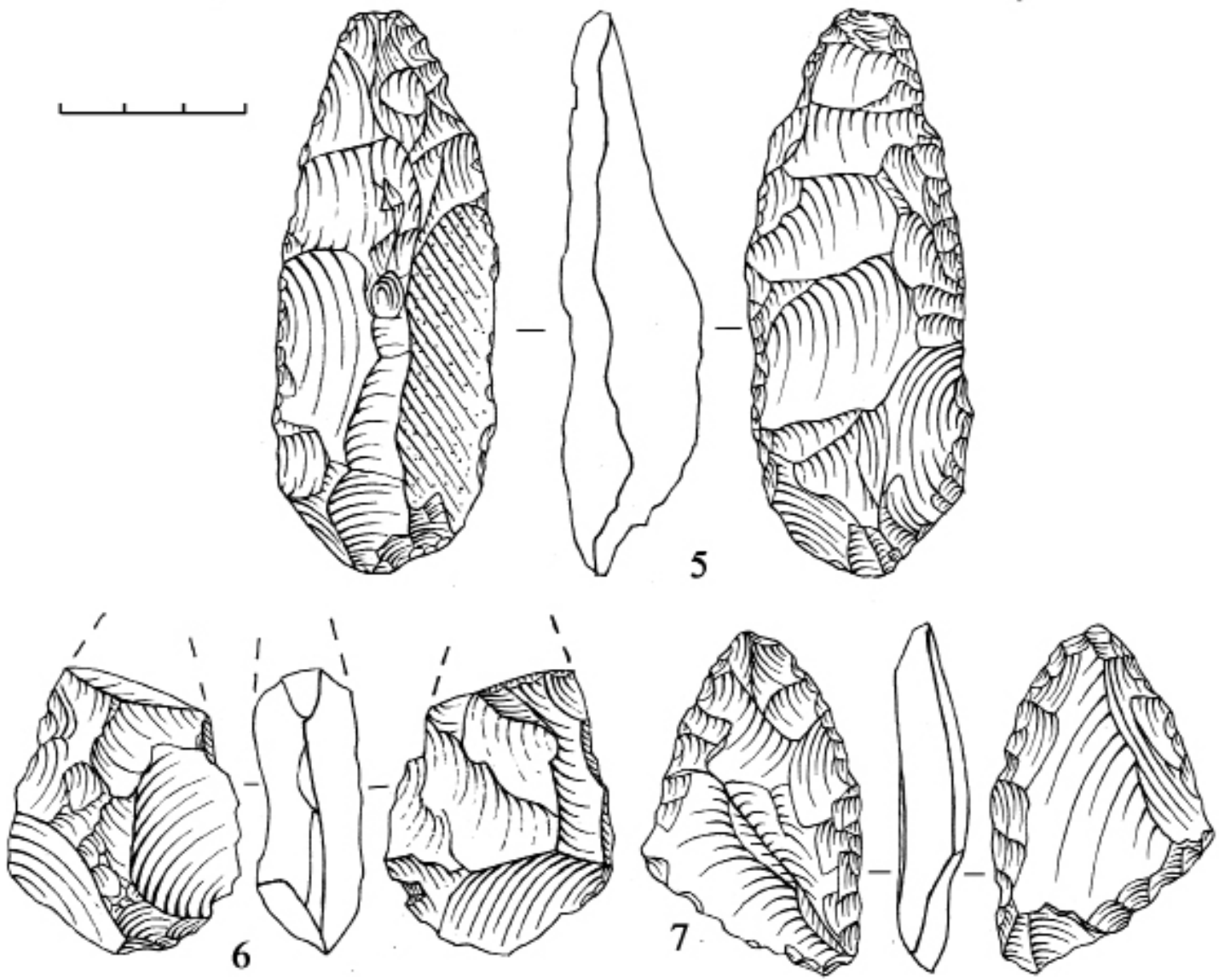

Puc. 6. Пещера Иманай-1. Бифациальные орудия из кремня: 1-4 - скребла конвергентные; 5-7 остроконечники

[Fig. 6. Imanai-1 Cave. Bifacial flint tools: $1-4-$ convergent scrapers; $5-7-$ points] 


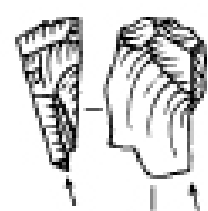

1 覧

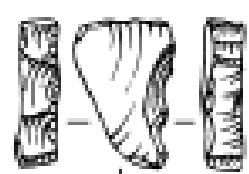

4 政

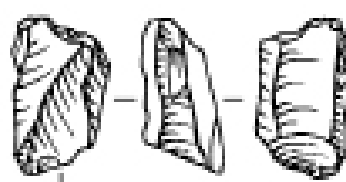

2

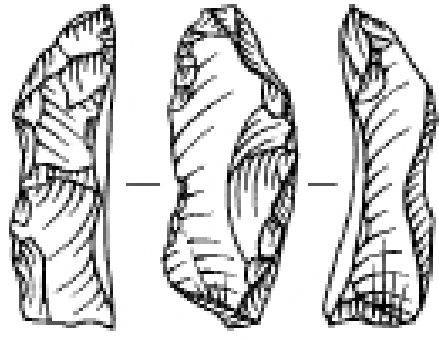

3

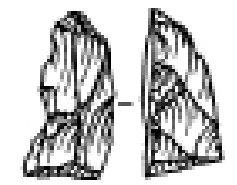

5

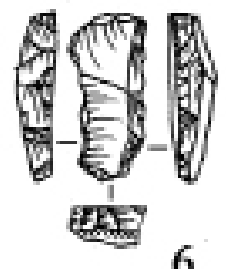

6

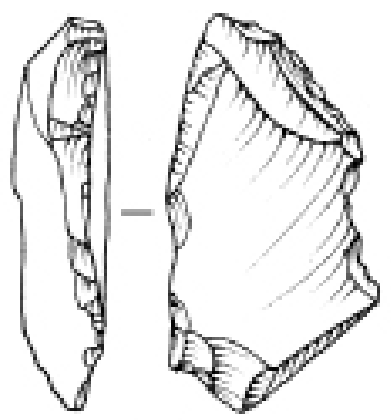

8
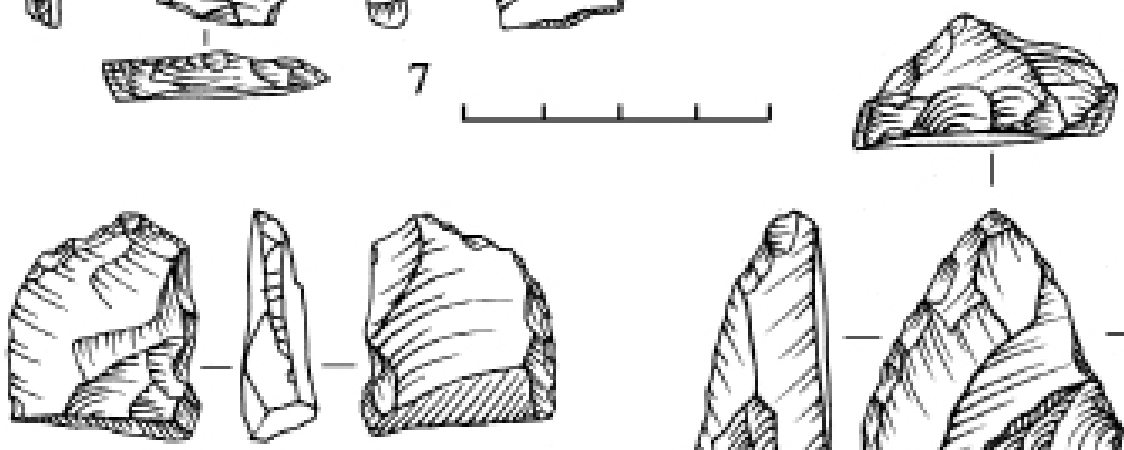

9
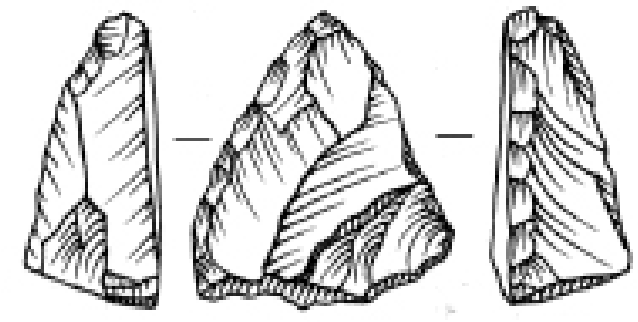

10

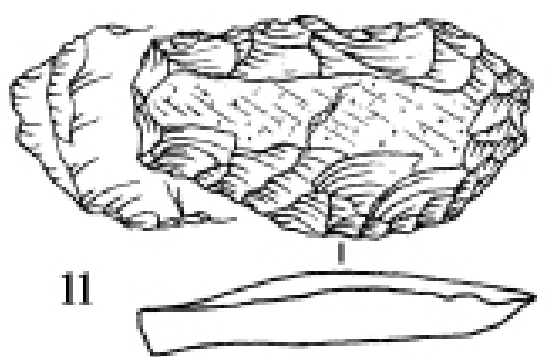

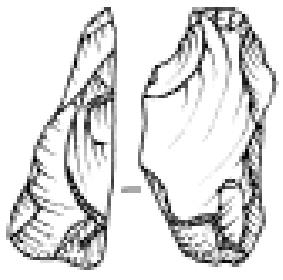

12

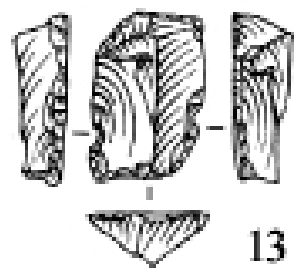

13

Puc. 7. Пещера Иманай-1. Кремневые изделия: 1 - скребок; 2 - скребок угловой; $3,5,12$ - скребок «с рыльцем»; 4, 6, 7, 13 - скребок с ретушированными краями; 8 - скребло прямое, скошенное; 9 - скребло поперечное, выпуклое; 10 - скребло продольное, скошенное с ретушированным основанием; 11 - скребок боковой «с рыльцем» - скребло двойное

[Fig. 7. Imanai-1 Cave. Flint products: 1 - scraper; 2 - corner scraper; 3, 5, 12 - scraper 'with stigma'; 4, 6, 7, 13 - scraper with retouched edges; 8 - straight scraper, beveled; 9 - transverse, convex scraper; 10 - longitudinal side-scraper, beveled with retouched base; 11 — side scraper 'with stigma' — double simple scraper] 

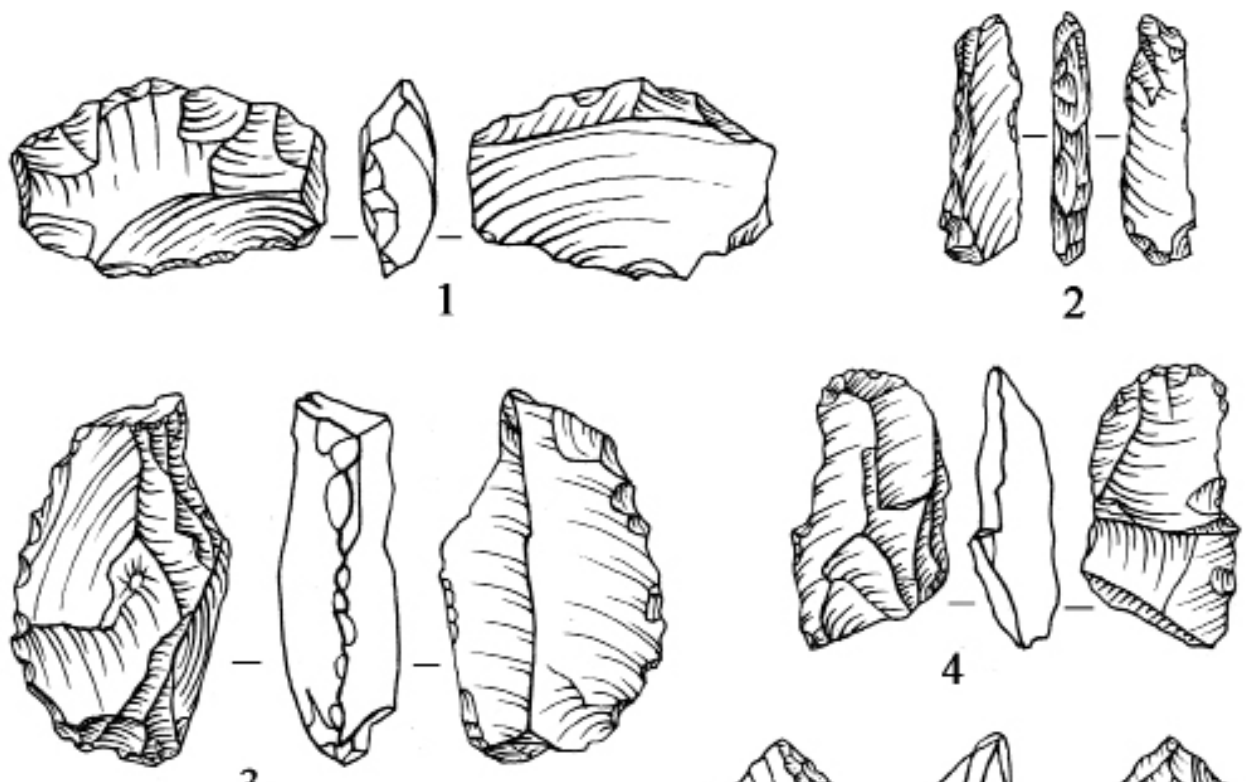

4
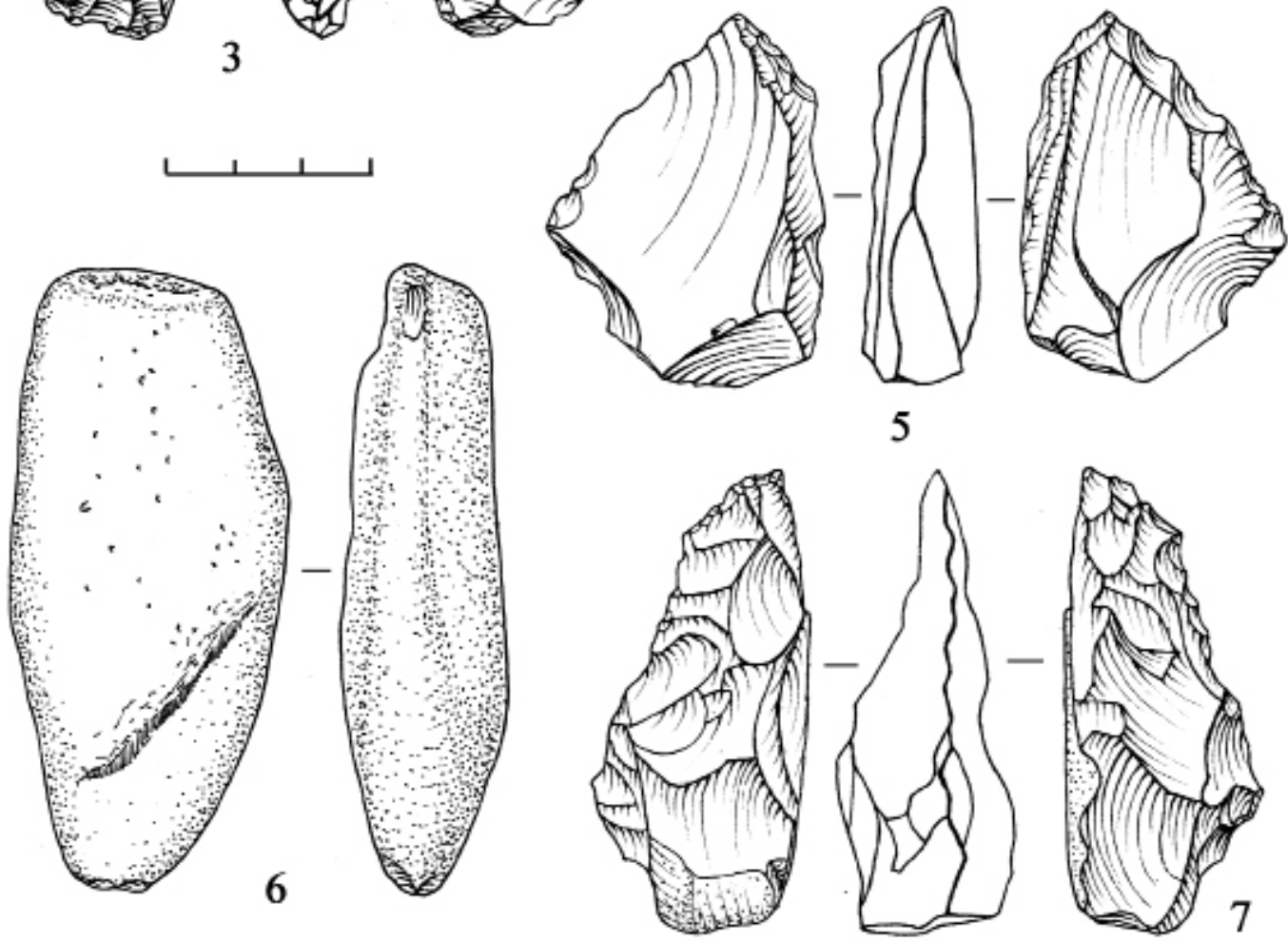

Puc. 8. Пещера Иманай-1. Каменные изделия. Ножи: 1 - с ретушированным обушком на укороченном отщепе; 2 - с ретушированным обушком и выделенным шиповидным острием на пластине; 3 - с обушком, созданным продольными сколами; 4 - с ретушированным закругленным обушком; 5 - с ретушированным прямым обушком; 7 - с естественным обушком и бифациальной обработкой поверхности. 6 - отбойник на гальке из кальцита. 1-5, 7 - кремень, 6 - кальцит

[Fig. 8. Imanay-1 Cave. Stone products. Knives: 1 — with a retouched back on a shortened flake; 2 - with a retouched back and a pronounced spiny point on the plate; 3 - with a backing created by longitudinal chips; 4 - with a retouched rounded back; 5 - with a retouched straight back; 7 - with natural back and bifacial surface treatment. 6 - bump stop on calcite pebbles. 1-5, 7 - flint, 6 - calcite] 


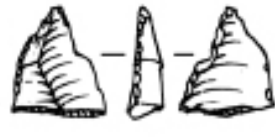

1

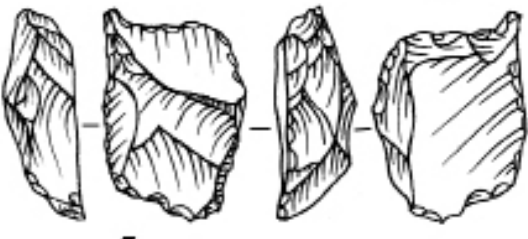

5

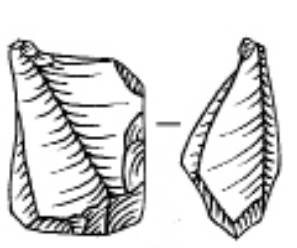

8
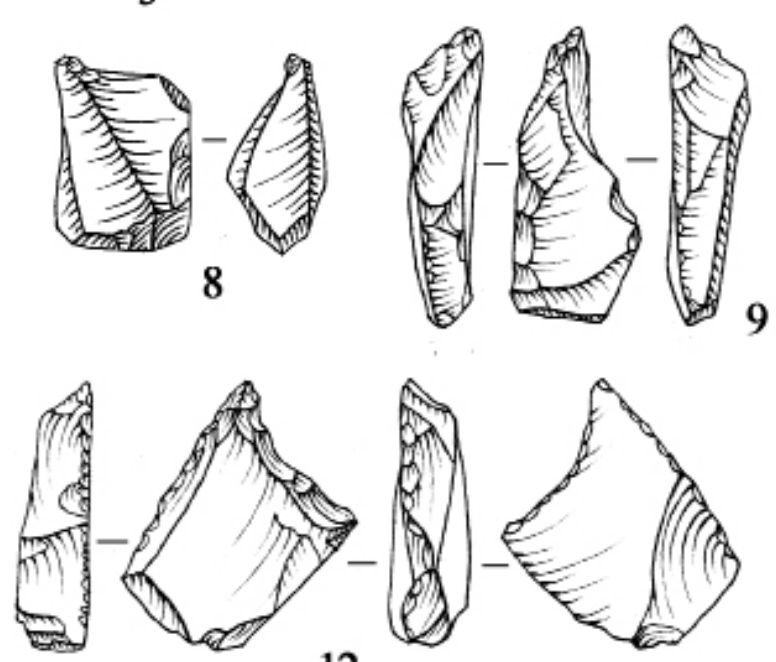

12
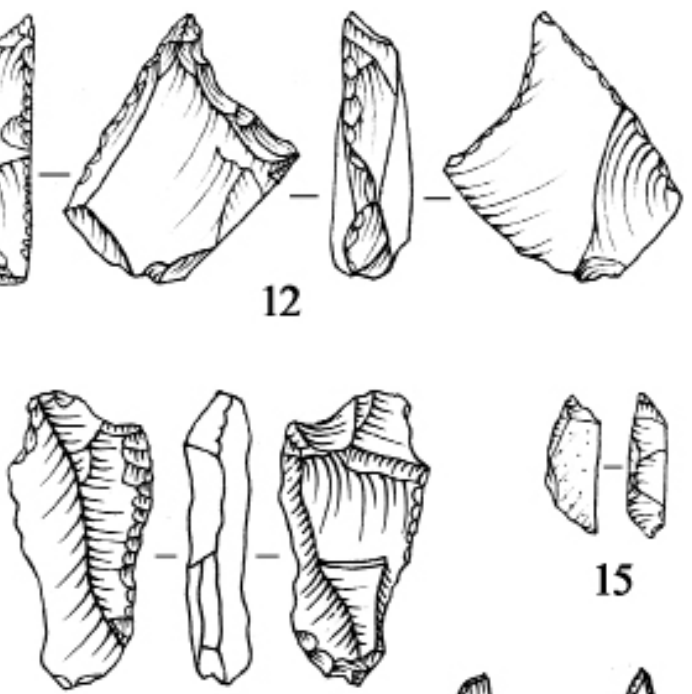

9

15

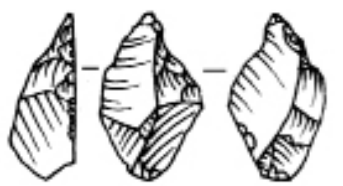

4

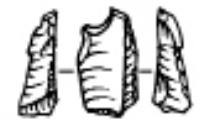

7

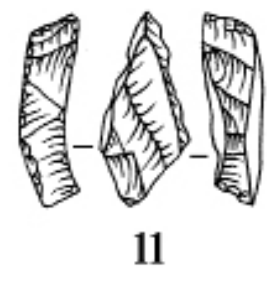

10

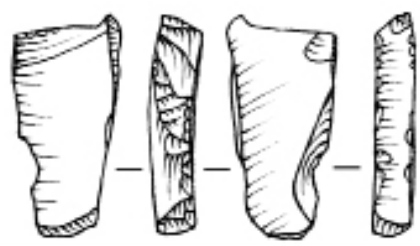

13
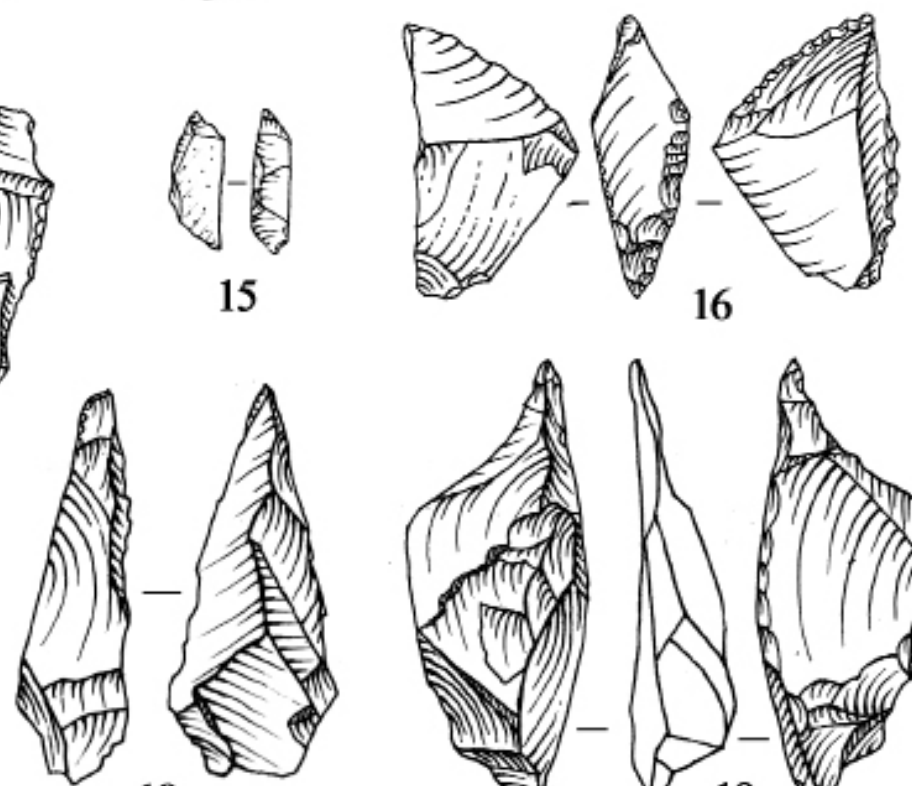

18

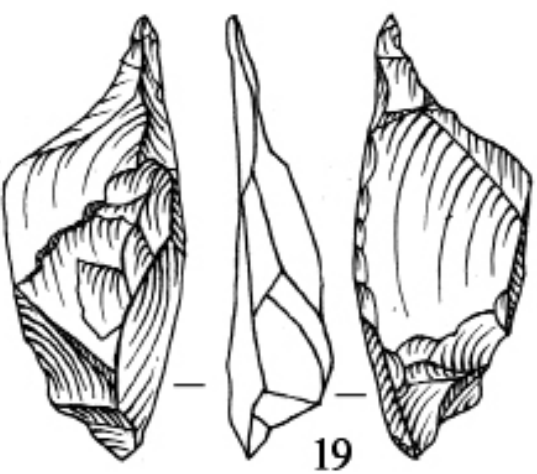

Puc. 9. Пещера Иманай-1. Острия из кремня: 1 - микроострие клювовидное с вентральной ретушью; 2, 3 - микроострие; 4 - острие бифациальное; 5, 6, 8-10, 12, 19 - острие клювовидное; 7, 16, 17 острие с анкошем; 13 - острие клювовидное ассиметричное; 14 - острие с плечиками; 11, 15, 18 - острие

[Fig. 9. Imanai-1 Cave. Flint points: 1 - beak-shaped micro-point with ventral retouch; 2,3 - a micropoint; 4 - a bifacial point; 5, 6, 8-10,12,19-a beak-shaped point; 7, 16, 17 - a point with ankosh; 13 - an asymmetric beak-shaped point; 14 - a point with shoulders; $11,15,18$ — point] 

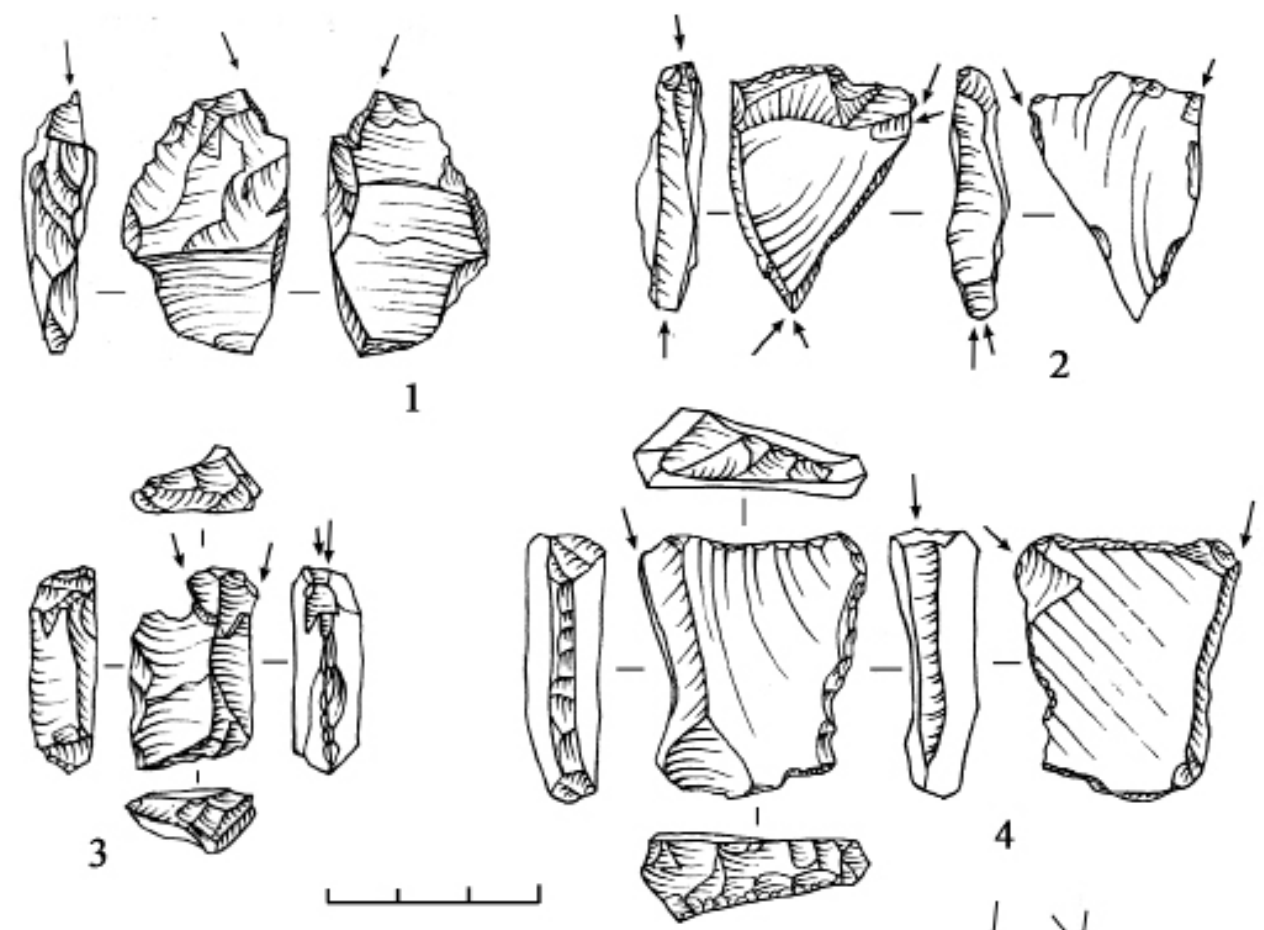

4
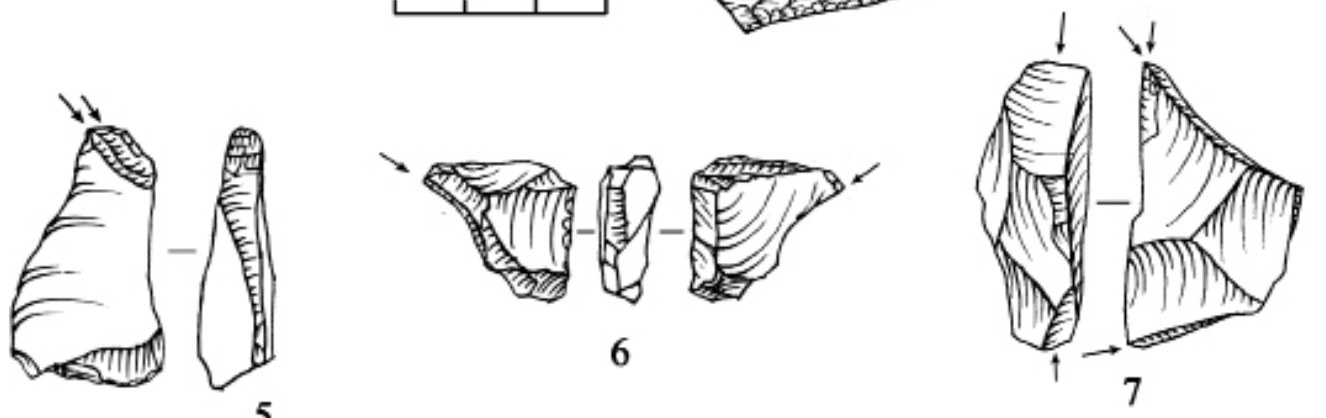

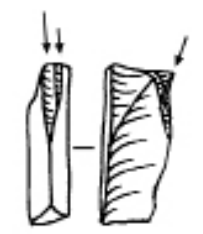

8

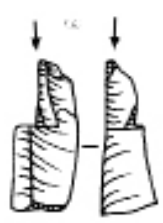

11

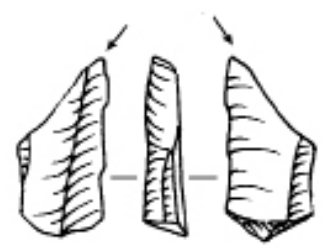

9

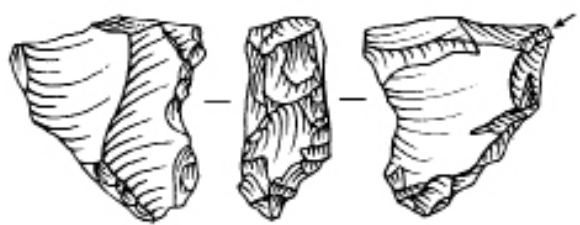

12
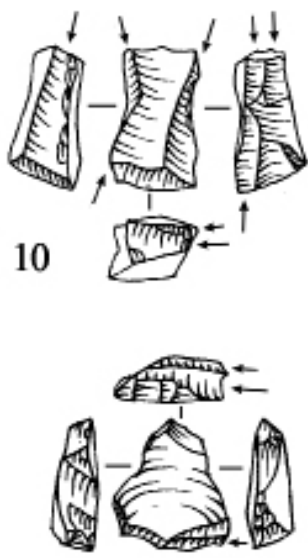

13

Puc. 10. Пещера Иманай-1. Резцы из кремня: 1 - резец-резчик; 2 - резец тройной; 3 - резец двойной; 4 - резец-скребок с ретушированными краями; 5, 12 - резец латеральный; 6 - резец клювовидный; 7 - резец двойной; 8, 11 - резец боковой; 9 - резец скошенный; 10 - резец четверной; 13 - резец площадочный

[Fig. 10. Imanai-1 Cave. Flint burins: 1 - burin-cutter; 2 - triple burin; 3 - double burin; 4 - scraperburin with retouched edges; 5, 12 - lateral burin; 6 - beak-shaped burin; 7 - double burin; 8, 11 lateral burin; 9 - beveled burin; 10 - quadruple burin; 13 — platform burin] 

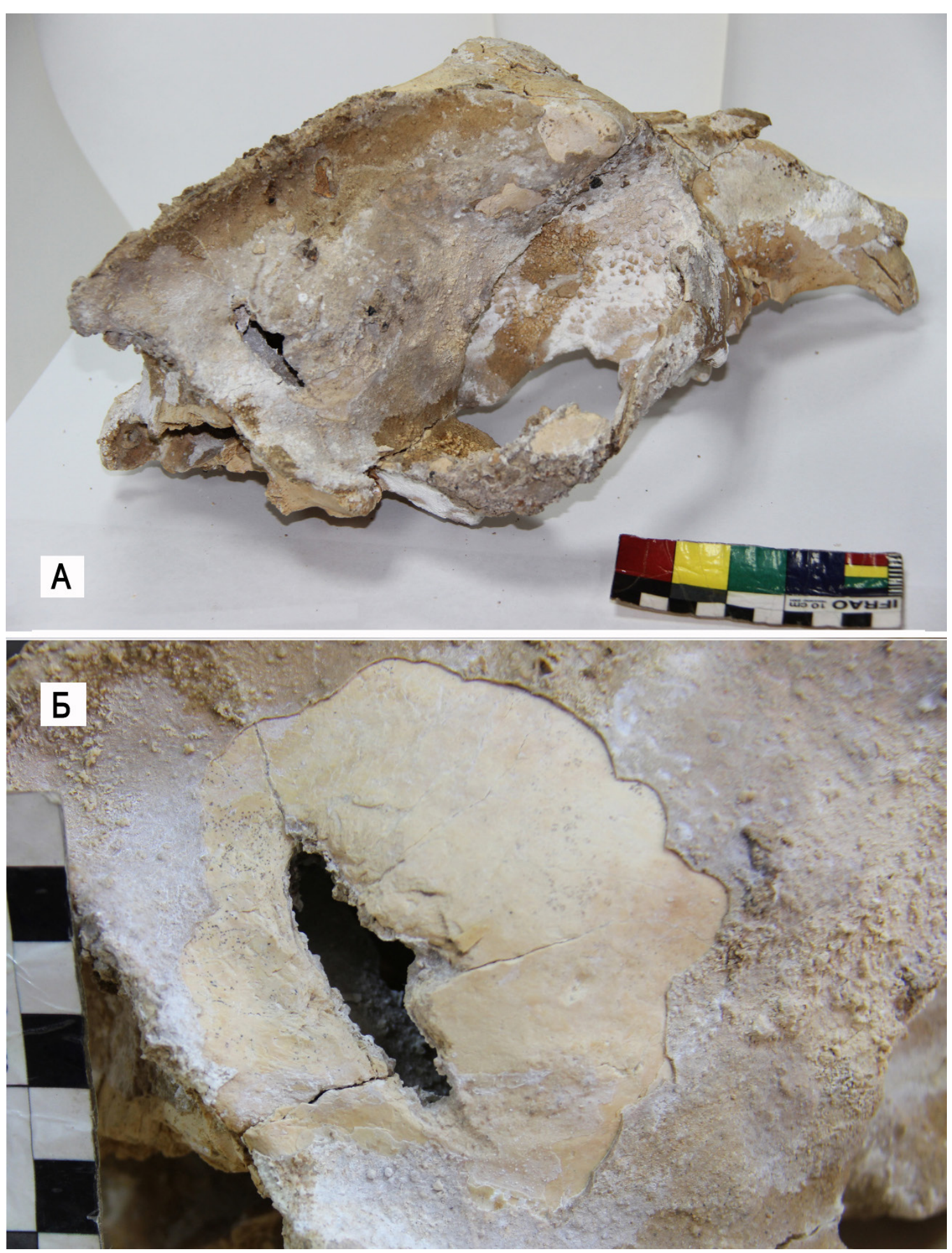

Puc. 11. Пещера Иманай-1, раскоп 1. А - череп малого пещерного медведя с искусственным отверстием, Б - искусственное отверстие в черепе малого пещерного медведя крупным планом. Фото В. Г. Котова

[Fig. 11. Imanai-1 Cave, excavation site 1. A — skull of a small cave bear with an artificial hole, B - closeup of an artificial hole in the skull of a small cave bear. Photo by V. Kotov] 
выпуклые края скребка с рыльцем и два выпуклых скребловидных края с вентральной подработкой продольными уплощающими сколами правого края (рис. 7: 11).

Во многом показательным является присутствие среди орудий на памятнике такой категории как обушковые ножи (6 экз.) (2 \%) (рис. 8). У одного изделия на укороченном отщепе (размер $2,7 \times 4,2 \times 1$ см) режущее лезвие было образовано одним широким сколом, снятым на спинке от основания, несколькими продольными сколами была дополнительно утончена дорсальная поверхность, обушковая грань обработана двумя сколами (рис. 8: 1). Другое орудие представляет из себя аморфную пластину, у которой одна продольная грань была сформирована вертикальной ретушью, а противоположный край пластины имеет естественную режущую кромку, также у изделия ретушью выделено шиповидное острие, размер: $3,5 \times 1 \times 0,5$ см (рис. 8: 2). Третье орудие было изготовлено на массивном отщепе, у него продольная грань была превращена на дистальной половине в обушок посредством ряда продольных торцевых снятий, спинка была утончена на проксимальной половине пологими длинными сколами радиальной направленности, а на вентральной стороне - одним продольным сколом, размер: $5,2 \times 3 \times 1,6$ см (рис. 8: 3). Еще у одного изделия продольными сколами было произведено утончение вентральной и дорсальной сторон, а затем мелкой крутой ретушью был образован закругленный обушок, размер: 4×2×1 см (рис. 8: 4). Точно так же была создана обушковая грань на другом орудии: у него продольными сколами была образована продольная грань, и участок, примыкающий к скошенному ретушированному лезвию, был дополнительно выровнен крутой ретушью, размер изделия: $5,2 \times 3,8 \times 1,5 \mathrm{~cm}$ (рис. 8: 5). У последнего орудия с естественным продольным обушком скошенное лезвие было образовано бифациальной обработкой, размер: 6,5×2,9×2,5 см (рис. 8: 7).

Среди орудийных форм в пещере Иманай-1 доминируют изделия остроугольной формы: резчики на остроугольных осколках и аморфных сколах - 229 экз. (57\%) и острия, также с бифациальной обработкой поверхности и рабочих участков - 19 экз. (5\%). У них разнообразной ретушью, торцевыми снятиями и ретушью с двух и более сторон выделены острия с режущими кромками. Размеры этих изделий от 1 до 5 см (рис. 9). У одних изделий острия имеют характер шипа, и они могли быть проколками (рис. 9: 1-10, 12, 19), в то время как у других массивные острия имеют режущие кромки, и они, скорее всего, являлись резчиками по мягко волокнистым материалам (рис. 9: 11, 13-18). У одного изделия бифациальной обработкой сформировано шиповидное острие с плечиками, подправленное противолежащей ретушью (рис. 9: 14). Сходные орудия с шипом имеются на стоянке в гроте Старые Дуруиторы [Анисюткин, Кетрару, Коваленко 2017: рис. $37: 4,6$; рис. 39: 1, 5].

За ними по количеству следуют различные резцы: боковые, поперечные, двойные и др. (21 экз. - 5 \%). Большая часть резцов - это боковые - 10 экз. (рис. 10: 1, 11), причем нередко многофасеточные - 6 экз. (рис. 10: 2, 3, 4, 7, 8, 10). Среди резцов есть латеральные - 3 экз. (рис. 10: $5,6,12$ ) и поперечные - 2 экз. (рис. 10: 9, 13).

В процессе раскопок был обнаружен череп малого пещерного медведя с искусственным отверстием в теменной кости (рис. 11: A). Вся поверхность черепа была покрыта тонким слоем кальцитового натека, вокруг отверстия кальцитовая корка нами была удалена. Ширина отверстия составляет 4 см, высота в срединной части составляет $1 \mathrm{~cm}$, причем в центре отмечена выемка до 1,3 см высотой, к краям высота отверстия доходит до 0,5 см. Края неровные, причем линия пролома со стороны затылка имеет изогнутые очертания. Внутри черепа на выступе на глубине 3 см от его поверхности видны две выемки. Судя по всему, череп медведя был пробит сильным ударом деревянного копья с каменным массивным наконечником с одной плоской и одной выпуклой стороной и продольной гранью в заднюю часть правой боковой поверхности головы медведя под углом $60^{\circ}$ к продольной оси черепа, и орудие вошло на глубину 3-4 см. Судя по многочисленным трещинам, удар был сделан по свежей кости, при этом животное в момент удара было подвижным, а само оружие не было выдернуто из раны. Это выразилось в многочисленных повреждениях краев отверстия и в желобчатой выемке от правого конца выемки (рис. 11: Б). Поскольку рана не имеет следов заживления, она была при- 
чиной смерти животного. Конфигурация отверстия свидетельствует в пользу того, что оно было сделано каменным орудием, очевидно, похожим на один из тех остроконечников, что были найдены в раскопе. Сцена охоты реконструируется приблизительно так: охотники подобрались вплотную к животному, удар был нанесен копьем сзади сверху, в момент удара голова малого пещерного медведя покоилась на какой-то твердой поверхности, что и позволило удержать копье с каменным наконечником в ране до полного обездвиживания тела. Вместе с тем, следует отметить, что на многочисленных костях малого пещерного медведя, найденных в ходе раскопок в пещере Иманай-1, каких-либо следов разделки туш медведя не было обнаружено. Это может указывать на то, что охота на малого пещерного медведя была спорадическим явлением и не являлась охотничьей специализацией древних людей, останавливающихся в пещере.

\section{Выводы}

Среди изделий подавляющее большинство - это бифациальные формы с грубой, неустойчивой по размеру, ретушью рабочих участков. Вместе с тем среди технических приемов вторичной обработки большое место занимает резцовый скол. Очевидно, на облик этой индустрии оказало качество пещерного кремня, из которого сделана часть орудий. Технико-типологический анализ показывает единство собранных каменных изделий из 1-го культурного слоя. Среди орудийных форм доминируют разнообразные резчики на остроугольных осколках и аморфных сколах. За ними следуют различные резцы: боковые, поперечные, двойные и др. Достаточно представительны разнообразные острия, также с бифациальной обработкой поверхности и рабочих участков. Типологический набор орудий и характер их использования указывает на то, что дальний зал пещеры Иманай-1 использовался для кратковременных стоянок охотников, которые здесь осуществляли починку охотничьего снаряжения и одежды. Большое количество резчиков может свидетельствовать о достаточно трудоемких по времени операциях по раскройке шкур. Отсутствие специализированных инструментов для изготовления одежды (проколки, провертки, скребки, иглы, скребла) позволяет думать, что эти операции были связаны, преимущественно, с изготовлением охотничьих приспособлений, например ловчих сетей из кожаных ремешков. Подобные ловчие сети широко использовались в охотничьем промысле коренным населением Сибири вплоть до XVIII в. [Андреев 1947].

Здесь были обнаружены конвергентные скребла с бифациальной обработкой и мустьерские бифациальные остороконечники. Данные орудия являются наиболее сложными в изготовлении и показательными. Они находят аналогии на мустьерских памятниках Кавказского региона и Крыма. Аналогичные изделия присутствуют в коллекции верхнего культурного слоя грота Киик-Коба: здесь имеются бифациальные массивные остроконечники плоско-выпуклых форм [Бонч-Осмоловский 1940: табл. XI; XII: 1, 2], такие же ручные рубильца [Бонч-Осмоловский 1940: табл. XVII: 1, 2], большое сходство с ассиметричным остроконечником из пещеры Иманай-1 имеет треугольное орудие с такой же крупной ретушью по периметру и уплощенным брюшком из грота Киик-Коба [Бонч-Осмоловский 1940: табл. XVI: 4].

Также конвергентные скребла с бифациальной обработкой из пещеры Иманай-1 буквально повторяют формы, представленные в 3 культурном слое на стоянке Ильская в Прикубанье на Северном Кавказе [Щелинский, Кулаков 2005].

Наряду с мустьерскими типами в коллекции присутствуют орудия верхнепалеолитического облика, в частности скребки и резцы. Подобное сочетание характерно в том числе и для тейякских памятников Ближнего Востока [Коробков 1978: 48-49].

Косвенно о возрасте памятника может говорить сходство этой индустрии с III слоем стоянки Ильская на Северном Кавказе, возраст этого слоя, по мнению автора раскопок - В. Е. Щелинского, древнее 85 тыс. лет [Щелинский 2009: 33].

В целом коллекция каменных и костяных орудий из отложений 1-го культурного слоя пещеры Иманай-1 демонстрирует архаические признаки в первичной и вторичной обработке, характерные для тейякской индустрии среднего палеолита. Пещера Иманай-1 - уникальный пещерный памятник такого возраста на Урале со столь насыщенным культурным слоем. 
Памятник является пещерной стоянкой древнего человека, которая неоднократно посещалась в течение длительного времени. Внутри пещеры обнаружены только единичные фрагменты костей, которые использовались в качестве орудий. Следов раскалывания костей малого пещерного медведя не обнаружено. Тем не менее находка черепа малого пещерного медведя с

\section{Источники}

Котов 2009 - Котов В. Г. Научный отчет о разведочных исследованиях в горной части Кугарчинского и Мелеузовского районов Республики Башкортостан в 2009 г. // Научный архив Института археологии РАН. Ф. Р-1. 109 c.

Котов 2015 - Котов B. Г. Научный отчет об археологических раскопках в пещере Иманай 1 (Барсучья Нора) Мелеузовского района Республики Башкортостан в 2015 г. // Научный архив Института археологии PAН. Ф. P-1. 213 c.

\section{Литература}

Андреев 1947 - Андреев А. И. «Описания о жизни и упражнении обитающих в Туруханской и Березовской округах разного рода ясачных иноверцах» Ивана Башкурова // Советская этнография. 1947. № 1. С 84-103.

Анисюткин, Кетрару, Коваленко 2017 Анисюткин Н. К., Кетрару Н. А., Коваленко С. И. Многослойная стоянка в гроте Старые Дуруиторы и место ее каменных индустрий в раннем и среднем палеолите Европы. СПб.: Нестор-История, 2017. 200 с.

Бонч-Осмоловский 1940 - Бонч-Осмоловский Г. А. Грот Киик-Коба. Палеолит Крыма. Вып. 1. М.; Л.: Изд-во АН СССР, 1940. 226 с.

Гимранов и др. 2016 - Гимранов Д. О., Котов В. Г., Румянцев М. М., Яковлев А. Г., Сотникова М. В., Нурмухаметов И. М., Сатаев Р. М., Косиниев П. А. Пещера Иманай - новое палеонтологическое и археологическое местонахождение на Южном Урале // 100-летие Палеонтологического общества России. Проблемы и перспективы палеонтологических исследований. Материалы LXII сессии Палеонтологического общества при РАН (4-8 апреля 2016 г., СанктПетербург). СПб.: Всероссийский геологический институт, 2016. С. 231-233.

Гимранов и др. 2018 - Гимранов Д. О., Котов В. Г., Румянцев М. М., Силаев В. И., искусственным отверстием указывает на возможность охоты древнего человека на это животное. Таким образом, остается вопрос о характере использования дальнего зала пещеры древними людьми (стоянка, убежище, место охоты или святилище?). В будущем планируется продолжение комплексных исследований на данном памятнике.

\section{Sources}

Kotov V. G. 2009 Exploratory Excavations in the Mountainous Part of Kugarchinsky and Meleuzovsky Districts, Bashkortostan (Russia): Scientific Report. At: Institute of Archaeology (RAS), Scientific Archive. Coll. P-1. 109 p. (In Russ.)

Kotov V. G. 2015 Archaeological Excavations in Imanai-1 Cave ('Badger Sett') of Meleuzovsky District, Bashkortostan (Russia): Scientific Report. At: Institute of Archaeology (RAS), Scientific Archive. Coll. P-1. 213 p. (In Russ.)

Яковлев А. Г., Яковлева Т. И., Зеленков Н. В., Сотникова М. В., Девяшин М. М., Пластеева Н. А., Зарецкая Н. Е., Нурмухаметов И. М., Смирнов Н. Г., Косинцеев П. А. Крупнейшее в Евразии захоронение ископаемых львов (Carnivora, Felidae, Panthera (Leo) ex gr. fossilis-spelaea) // Доклады Академии наук. 2018. Т. 482. № 2. C. 231-234.

Коробков 1978 - Коробков И. И. Палеолит Восточного Средиземноморья // Палеолит Ближнего и Среднего Востока. Палеолит мира. Л.: Наука, 1978. С. 9-154.

Котов 2008 - Котов В. Г. Костяная индустрия мустьерской стоянки Новобелокатайская на северо-востоке Башкортостана // Уфимский археологический вестник. 2008. Вып. 8. C. $8-23$.

Широков и др. 2011 - Широков В. Н., Волков Р. Б., Косинцев П. А., Лаптева Е. Г. Палеолитическая стоянка Богдановка (Южный Урал) // Российская археология. 2011. № 1. С. 125-139.

Щелинский 2009 - Щелинский В. Е. Ильская стоянка на Кубани. Уникальный памятник среднего палеолита на территории России // Археологические открытия, 1991-2004 гг. Европейская Россия. М.: Ин-т археологии PAH, 2009. С. 23-34.

Щелинский, Кулаков 2005 - Щелинский B. E., Кулаков С. А. Ильская мустьерская стоян- 
ка (раскопки 1920-х - 1930-х годов). СПб. Европейский Дом, 2005. 96 с.

Gimranov et al.2018 - GimranovD. O., Kotov V. G., Rumyantsev M. M., Silaev V. I., Yakovlev A. G., Yakovleva T. I., Zelenkov N. V., Sotnikova M. V., Devyashin M. M., Plasteeva N. A., Zaretskaya N. E., Nurmukhametov I. M., Smirnov N. G., Kosintsev P. A. A Mass Burial

\section{References}

Andreev A. I. 'Description of Life and Practices of Diverse Non-Russian Yasak Tribes Inhabiting Turukhansk and Berezovskoe Districts' by Ivan Bashkurov. Sovetskaya etnografiya. 1947. No. 1. Pp. 84-103. (In Russ.)

Anisyutkin N. K., Ketraru N. A., Kovalenko S. I. The Multilayered Site in Starye Duruitory Grotto and Place of Its Stone Industries: Europe's Early and Middle Paleolithic. St. Petersburg: Nestor-Istoriya, 2017. 200 p. (In Russ.)

Bonch-Osmolovsky G. A. Kiik-Koba Grotto: Paleolithic in the Crimea. Vol. 1. Moscow; Leningrad: USSR Academy of Sciences, 1940. 226 p. (In Russ.)

Gimranov D. O., Kosintsev P. A. Quaternary large mammals from the Imanay Cave. Quaternary International. 2020. No. 546. Pp. 125-134. (In Eng.)

Gimranov D. O., Kotov V. G., Rumyantsev M. M. et al. A mass burial of fossil lions (Carnivora, Felidae, Panthera (Leo) ex gr. fossilisspelaea) from the Eurasia. Doklady Akademii Nauk. 2018. Vol. 482. No. 2. Pp. 231-234. (In Russ.)

Gimranov D. O., Kotov V. G., Rumyantsev M. M. et al. A Mass Burial of Fossil Lions (Carnivora, Felidae, Panthera (Leo) ex gr. fossilis-spelaea) from Eurasia. Doklady Biological Sciences. 2018, September. Vol. 482. No. 1. Pp. 191-193. (In Eng.) of Fossil Lions (Carnivora, Felidae, Panthera (Leo) ex gr. fossilis-spelaea) from Eurasia // Doklady Biological Sciences. September 2018. Vol. 482. Is. 1. Pp 191-193.

Gimranov, Kosintsev 2020 - Gimranov D. O., Kosintsev P. A. Quaternary large mammals from the Imanay Cave // Quaternary International. 2020. № 546. Pp. 125-134.

Gimranov D. O., Kotov V. G., Rumyantsev M. M. et al. Imanai Cave - - a new paleontological and archaeological site in the Southern Urals. In: Celebrating the $100^{\text {th }}$ Anniversary of Russian Paleontological Society. Session Proceedings (St. Petersburg; April 4-8, 2016). St. Petersburg: Russian Geological Research Institute, 2016. Pp. 231-233. (In Russ.)

Korobkov I. I. Paleolithic in the Eastern Mediterranean. In: Paleolithic in the Near and Middle East. Ser.: Paleolithic and the World. Leningrad: Nauka, 1978. Pp. 9-154. (In Russ.)

Kotov V. G. Bone industry in the Mousterian site of Novobelokatayskaya, northeastern Bashkortostan. The Ufa Archaeological Herald. 2008. Vol. 8. Pp. 8-23. (In Russ.)

Shchelinsky V. E., Kulakov S. A. The Mousterian Site of Ilsky Excavated: 1920s - 1930s. St. Petersburg: Evropeyskiy Dom, 2005. 96 p. (In Russ.)

Shchelinsky V. E. The site of Ilsky (Kuban) - a unique monument of the Middle Paleolithic in Russia. In: Archaeological Discoveries of 1991-2004. European Russia. Moscow: Institute of Archaeology (RAS), 2009. Pp. 23-34. (In Russ.)

Shirokov V. N., Volkov R. B., Kosintsev P. A., Lapteva E. G. The Paleolithic dwelling site of Bogdanovka (South Urals). Russian Archaeology. 2011. No. 1. Pp. 125-139. (In Russ.) 